\title{
Microbiolization of Seeds and Aerial Application With Yeasts for Disease Control in Wheat
}

\author{
Rayssa H. da Silva ${ }^{1}$, Renata F. Barabasz ${ }^{1,2}$, Monica C. Sustakowski ${ }^{1,3}$, Odair J. Kuhn ${ }^{1,4}$, Jeferson C. Carvalho ${ }^{1,5}$, \\ Willian dos Reis ${ }^{1,6}$, José R. Stangarlin ${ }^{1,7}$ \& Vinícius H. D. de Oliveira ${ }^{2}$ \\ ${ }^{1}$ Agricultutal Science Center, State University of Western Paraná, Marechal Cândido Rondon, Paraná, Brazil \\ ${ }^{2}$ Engineering, Mathematics and Technology, State University of Western Paraná, Cascavel, Paraná, Brazil \\ Correspondence: Rayssa H. da Silva, Agricultutal Science Center, State University of Western Paraná, \\ Pernambuco Street, 1777, Marechal Cândido Rondon, 85960-000, Paraná, Brazil. Tel: 55-48-98831-1399. \\ E-mail: ray.helana@hotmail.com
}

Received: August 5, 2020

Accepted: September 6, 2020

Online Published: September 15, 2020

doi:10.5539/jas.v12n10p307

URL: https://doi.org/10.5539/jas.v12n10p307

The research is financed by Fundação Araucária.

\begin{abstract}
Wheat productivity is compromised by the number of diseases that affect it. The diseases control is basically effected by the use of fungicides, however, biological control has become important due especially to the demand for foods free of chemical compounds. The objective of this work was to evaluate the efficiency of yeasts in reducing diseases through the treatment of wheat seeds and the spraying of plants in the field. The tests were carried out in the field and laboratory, with the yeasts Candida albicans, Cryptococcus laurentii, Pichia guilliermondii, Rhodotorula glutinis, Zygoascus hellenicus and Saccharomyces cerevisiae compared with fungicide (carbendazim) and control with water. In the laboratory, seed health, germination, germination speed index, cold test and accelerated aging were analyzed. In the field, seed treatment and aerial application were carried out when the flag leaf was emitted and the occurrence of diseases, chlorophyll content, production components, productivity and production quality was evaluated. For the variables of production and quality of the wheat in field, the yeast $Z$. hellenicus was efficient for productivity resembling the fungicide. For the severity of diseases in field, parameters related to germination and seed health, yeasts were not efficient.
\end{abstract}

Keywords: biological control, germination test, plant health, Triticum aestivum L., Zygoascus hellenicus

\section{Introduction}

Wheat (Triticum aestivum L.) stands out for being the most economically important crop among winter cereals. Production in Brazil was 5.4 million tons according to FAO (2018). With the occurrence of rain, phytosanitary problems are favored, being common rot (Bipolaris sorokiniana), leaf rust (Puccinia triticina), blast fungus (Pyricularia grisea), powdery mildew (Blumeria graminis sp. tritici), brown spot (Bipolaris sorokiniana), glume spot (Stagonospora nodorum), gibberell (Gibberella zeae) and yellow spot (Drechslera tritici-repentis) the main diseases according to Silva, Bassoi, and Foloni (2017).

Chemical disease control has been the main method used to manage diseases, mainly due to its effectiveness and economic viability (Silva Junior \& Behlau, 2018). However, the continuous use of agrochemicals poses risks to the environment due to the persistence of residues in the soil and contamination of groundwater, impacting terrestrial and aquatic ecosystems, also causing serious impacts on human health (Wightwick, Walters, Allison, Reichman, \& Menzies, 2010; Pereira, Costa, \& Lima, 2019), in addition to their loss of efficiency due to the resistance acquired by pathogens. Therefore, the use of alternative methods should be better explored in the diseases control.

According to Medeiros, Silva, and Pascholati (2018), biological diseases control occurs through the control of pathogenic microorganisms by the action of another, this can occur through mechanisms of action such as antibiosis, competition, parasitism and predation, as well as through the induction of resistance. 
Yeasts stand out among the organisms with potential for alternative control because they are promising agents of disease control and for participating in the epiphytic/endophytic microbiota, competing with pathogens (Mello, Silveira, Viana, Guerra, \& Mariano, 2011), such as the yeasts Pichia spp. and Candida spp. which has been effective in reducing the use of systemic fungicides, especially in post-harvest (Liu, Sui, Wisniewski, Droby, \& Liu., 2013).

In the work of Roberts (1990) the presence of Cryptococcus laurentii in apple fruits in post-harvest was able to inhibit and reduce the percentage of fruits with gray mold (Botrytis cinerea). There are reports of in vitro inhibition of the growth of Fusarium sporotrichioides colonies by isolates of Rhodotorula glutinis and Saccharomyces cerevisiae yeasts (Wachowska, Kucharska, Jędryczka, \& Łobik, 2013).

According to Heling (2016), plants treated with Pichia guilliermondii in a greenhouse obtained an area reduction of $30.40 \%$ under the common bacterial blight progress curve and plants treated with Zygoascus hellenicus showed a reduction of 11.43 and $19.35 \%$ in field in the water harvest (2015/2016).

Therefore, the objective of this work was to evaluate the efficiency of yeasts in reducing diseases through the treatment of wheat seeds and spraying of plants in the field.

\section{Method}

The work was carried out in Marechal Cândido Rondon- PR, located at $24^{\circ} 53^{\prime} \mathrm{S}, 54^{\circ} 02^{\prime} \mathrm{W}$ and altitude of $387 \mathrm{~m}$, from May 2017 to May 2018 in two stages. One in field conditions with a focus on leaf diseases and the second in laboratory conditions with a focus on seed quality and health.

The first stage was developed in a randomized block design with eight treatments and four blocks. The experimental units were defined with 10 spaced lines of $0.20 \mathrm{~m}$ and density of 60 plants per meter of the cultivar CD-150.

Fertilization was carried out at planting and covering at the tillering stage according to the soil analysis and recommendations (Oliveira, 2003). The other cultural treatments were carried out according to the culture needs during the experiment.

On the issuance of the flag leaf was spraying suspensions of Candida albicans, Cryptococcus laurentii, Pichia guillermondii, Rhodotorula glutinis, Zygoascus helenicus, Saccharomyces cerevisiae yeasts in the concentration of $1 \times 10^{8}$ cells $\mathrm{mL}^{-1}$ and compared with the treatment with fungicide (carbendazim) and control with distilled water. At 10 days after application, the chlorophyll index was evaluated with a Minolta Chlorophyllometer (model SPAD-502) on the flag sheet.

The disease evaluation was carried out at the flowering stage, with the aid of diagrammatic scales for the yellow spot (James, 1971), blast fungus (Maciel, Danelli, Boaretto, \& Forcelini, 2013), glume spot (Thapa et al., 2016) and leaf rust (Alves et al., 2015), where percentages of disease severity were attributed to leaf or glume.

When the plants reached physiological maturity, the six central lines were harvested, evaluating the number of plants, number of tillers, plant height (Zadoks, Chang, \& Konzak, 1974), number of ears $\mathrm{m}^{-2}$, number of spikelets per ear, number of grains per ear, mass of a thousand grains and estimate of productivity and quality (Hossen, Corrêa Junior, Guimarães, Nunes, \& Galon, 2014) of production determined by hectoliter weight, standardized at $13 \%$ humidity.

The second stage was conducted in the laboratory, with the seeds of cultivar CD-150 subjected to the same treatments with a completely randomized design with four replications. Seed health tests, emergence and germination speed index, cold test, accelerated aging test, seedling length, root length and fresh and dry mass of seedlings and roots were performed.

The seeds microbiolization was carried out with $0.20 \mathrm{~mL}$ of yeast suspension $\left(1 \times 10^{8}\right.$ cells $\left.\mathrm{mL}^{-1}\right)$, water or fungicide and applied to a portion of $100 \mathrm{~g}$ of seed, according to the recommended fungicide dose.

The seed health test was conducted with 200 seeds per treatment placed in transparent acrylic boxes lined with moist paper towels. After $24 \mathrm{~h}$, the boxes remained in the freezer for $12 \mathrm{~h}$ for inactivity of the seed embryo (Machado, Pereira, Valle, \& Alvisi, 2009), and then 7 days at room temperature. Then, fungal structures were identified at the gender level through the Barnett and Hunter manual (1998) and quantified the healthy seeds and infected with each pathogen.

In the germination test, four repetitions of 50 seeds were placed in rolled paper towels at $20^{\circ} \mathrm{C}$ and a 12 hours photoperiod for 8 days in plastic bags. On the fourth day, normal seedlings were quantified and on the eighth day, normal, abnormal and non-germinated seedlings were quantified (Brasil, 2009). The germination speed index was also obtained (Maguire, 1962). 
The length of the aerial part of seedlings and radicle, fresh and dry mass of the aerial part and the radicle of seedlings were evaluated (Nakagawa, 1999). In the cold test, four repetitions of 50 seeds were placed in rolled paper towels at $5{ }^{\circ} \mathrm{C}$ for 7 days (Fanan, Lima, \& Marcos Filho, 2006), afterwards, they were kept at $20^{\circ} \mathrm{C}$ for 8 days. Quantification was performed on the fourth and eighth day according to the germination test described above.

The accelerated aging test used 200 seeds per treatment placed on plastic screens in transparent acrylic boxes with a lid moistened with $40 \mathrm{~mL}$ of water. After $48 \mathrm{~h}$ at $43^{\circ} \mathrm{C}$ inside the aging chamber (Lima, Medina, \& Fanan, 2006), the seeds were placed in rolled paper towels and kept for 8 days at $20^{\circ} \mathrm{C}$ as previously described.

The data were subjected to normality tests. For analysis of variance and comparison of means by the Tukey test at 5\% probability was used the SISVAR 5.3 statistical program. For the cold and accelerated aging tests, the means were compared using the Dunnet test at $5 \%$ probability with the aid of Genes statistical program.

\section{Results and Discussions}

After the application of yeasts to the field, no significant difference was observed between treatments for the variables number of plants per meter, number of tillers per meter, number of spikelet per ear, number of grains per ear and number of ear per square meter. The general averages were 14.72; 95.91; 11.62; 17.67 and 171.19, respectively and the other data were omitted.

The average value for number of grains per ear (17.67) was lower than the work by Chavarria, Rosa, Hoffmann and Durigon (2015) who found to cultivate Mirante 34.49 and to cultivate Quartz, 35.95 grains per ear when growth regulator is applied to plants. The reduced number of grains per ear can be explained by the water deficiency that occurred during the experiment, mainly in the grain filling period, a phase that is usually sensitive to summer (Ribeiro Júnior et al., 2006).

During the filling of grains, which occurred at the beginning of the second ten-day period in August until the end of the first ten-day period in September, the water requirement is about $5.48 \mathrm{~mm} \mathrm{day}^{-1}$ (Libardi \& Costa, 1997). However, in August and September, the average precipitation was $3.40 \mathrm{~mm}$ and $0.00 \mathrm{~mm}$ in the experimental area (INMET, 2017), respectively, not being enough for the correct formation of grains. Wilcox and Makowski (2014) conclude that wheat yield can be reduced due to scarcity of rainfall and high temperatures.

The means by treatment of the variables plant height, mass of thousand grains, and chlorophyll index (SPAD) were not significant (data not shown). There was a significant difference between treatments for productivity and hectoliter weight (Table 1).

Table 1. Productivity (PROD) and hectoliter weight (HW) of wheat plant grains sprayed with yeasts at field and yellow spot severity observed in the field. Marechal Cândido Rondon, 2017.

\begin{tabular}{llll}
\hline Treatment & PROD $\left(\mathrm{kg} \mathrm{ha}^{-1}\right)$ & HW $\left(\mathrm{kg} 100 \mathrm{~L}^{-1}\right)$ & Yellow spot \\
\hline Control & $590.50 \mathrm{~b}$ & $79.51 \mathrm{abc}$ & $0.50 \mathrm{~b}$ \\
P. guilliermondii & $721.25 \mathrm{ab}$ & $79.59 \mathrm{abc}$ & $0.45 \mathrm{~b}$ \\
S. cerevisiae & $789.25 \mathrm{ab}$ & $77.59 \mathrm{c}$ & $0.15 \mathrm{~b}$ \\
C. albicans & $730.75 \mathrm{ab}$ & $78.06 \mathrm{bc}$ & $2.68 \mathrm{a}$ \\
C. laurentii & $791.00 \mathrm{ab}$ & $81.05 \mathrm{ab}$ & $0.45 \mathrm{~b}$ \\
Z. hellenicus & $948.00 \mathrm{a}$ & $81.51 \mathrm{a}$ & $0.50 \mathrm{~b}$ \\
R. glutinis & $759.75 \mathrm{ab}$ & $80.96 \mathrm{ab}$ & $1.00 \mathrm{ab}$ \\
Fungicide & $668.00 \mathrm{ab}$ & $79.15 \mathrm{abc}$ & $0.60 \mathrm{~b}$ \\
CV\% & 15.94 & 1.67 & 23.72 \\
Overall Average & 749.81 & 79.68 & 0.79 \\
\hline
\end{tabular}

Note. Averages followed by the same lower case letter in the column, do not differ statistically from each other, tukey test at the level of $\mathrm{p} \leq 0.05$.

The yeast $Z$. hellenicus stands out for differing statistically from the control, being possible to say that it helped in maintaining the productivity even in the adverse conditions of drought while the culture was in the field.

The foliar application of yeasts can promote the increase of grain yield (Mohamed, Thalooth, Essa, \& Godarah, 2018), however the productivity values were lower than the studies by Battistus et al. (2013) who obtained an average of $1131.25 \mathrm{~kg} \mathrm{ha}^{-1}$ without application of fungicide in aerial parts and by Marinho, Bazzo, Cardoso, 
Zucareli and Fonseca (2018) who obtained 3805.58 and $3315.95 \mathrm{~kg} \mathrm{ha}^{-1}$ with the genotypes BRS Gralha-azul and BRS Sabiá, respectively.

For hectoliter weight, the treatment with Z. hellenicus obtained $81.51 \mathrm{~kg} \mathrm{hL}^{-1}$, differing only from the treatments with $S$. cereviseae and C. albicans, 77.59 and $78.06 \mathrm{~kg} \mathrm{hL}^{-1}$, respectively, being similar to the results of Prando, Zucareli, Fronza, Oliveira and Oliveira Júnior (2013) where in the first year of the experiment, it was classified as type 1, according to Silva et al. (2017).

The evaluation of diseases under field conditions revealed the occurrence of leaf rust, yellow spot and glume spot, but there was no significant difference for leaf rust and glume spot, being omitted.

The development of diseases occurs due to the interaction between pathogen, susceptible plant and favorable environment (Medeiros et al., 2018). Therefore, the condition of low rainfall precipitated the occurrence of diseases and the effect of yeasts on biological diseases control in the crop was not verified. C. albicans favored an increase in the severity of yellow spot, increasing from $0.5 \%$ (control) to $2.68 \%$ in severity (Table 1).

The evaluations of vigor and quality of seeds had a significant effect on the variables length of aerial part and radicle, fresh and dry seedling mass, germination speed index, germination on the fourth day (first count) and germination test (Table 2). The variables fresh and dry root mass and emergence speed index were not significant (data not shown).

Table 2. Seedling shoot length (SSL), root length (RL), seedling shoot fresh mass (SSFM), seedling shoot dry mass (SSDM), germination speed index (GSI), seeds germinated on the fourth day-first count (FC) and the germination test (GT) of wheat seeds treated with yeasts. Marechal Cândido Rondon, 2017

\begin{tabular}{llllllll}
\hline Treatment & SSL $(\mathrm{cm})$ & RL $(\mathrm{cm})$ & SSFM $(\mathrm{g})$ & SSDM $(\mathrm{g})$ & GSI & FC $(\%)$ & GT $(\%)$ \\
\hline Control & $11.31 \mathrm{a}$ & $13.06 \mathrm{a}$ & $0.80 \mathrm{a}$ & $0.080 \mathrm{a}$ & $24.80 \mathrm{bcd}$ & $38.5 \mathrm{ab}$ & $69.0 \mathrm{abc}$ \\
P. guilliermondii & $10.69 \mathrm{ab}$ & $11.25 \mathrm{ab}$ & $0.65 \mathrm{abc}$ & $0.063 \mathrm{ab}$ & $20.22 \mathrm{~d}$ & $22.0 \mathrm{~cd}$ & $58.5 \mathrm{c}$ \\
S. cerevisiae & $9.35 \mathrm{~b}$ & $9.44 \mathrm{~b}$ & $0.57 \mathrm{c}$ & $0.056 \mathrm{~b}$ & $20.64 \mathrm{~cd}$ & $20.5 \mathrm{~d}$ & $60.5 \mathrm{bc}$ \\
C. albicans & $10.06 \mathrm{ab}$ & $10.37 \mathrm{ab}$ & $0.64 \mathrm{bc}$ & $0.065 \mathrm{ab}$ & $27.63 \mathrm{ab}$ & $36.0 \mathrm{abc}$ & $67.0 \mathrm{abc}$ \\
C. laurentii & $9.94 \mathrm{ab}$ & $11.72 \mathrm{ab}$ & $0.62 \mathrm{bc}$ & $0.060 \mathrm{ab}$ & $27.98 \mathrm{ab}$ & $41.0 \mathrm{ab}$ & $72.0 \mathrm{ab}$ \\
Z. hellenicus & $10.35 \mathrm{ab}$ & $10.81 \mathrm{ab}$ & $0.60 \mathrm{bc}$ & $0.058 \mathrm{~b}$ & $26.7 \mathrm{abc}$ & $35.0 \mathrm{abcd}$ & $73.0 \mathrm{ab}$ \\
R. glutinis & $10.35 \mathrm{ab}$ & $11.16 \mathrm{ab}$ & $0.66 \mathrm{abc}$ & $0.061 \mathrm{ab}$ & $24.75 \mathrm{bcd}$ & $26.0 \mathrm{bcd}$ & $73.0 \mathrm{ab}$ \\
Fungicide & $10.70 \mathrm{ab}$ & $14.10 \mathrm{a}$ & $0.74 \mathrm{ab}$ & $0.071 \mathrm{ab}$ & $31.74 \mathrm{a}$ & $49.5 \mathrm{a}$ & $75.5 \mathrm{a}$ \\
CV\% & 2.80 & 6.33 & 1.96 & 0.39 & 5.29 & 10.89 & 4.05 \\
Overall Average & 10.37 & 11.49 & 0.66 & 0.065 & 25.56 & 33.56 & 68.56 \\
\hline Note. Avv
\end{tabular}

Note. Averages followed by the same lower case letter in the column, do not differ statistically from each other, tukey test at the level of $\mathrm{p} \leq 0.05$.

Seedling shoot length (SSL), radicle length (RL), seedling shoot fresh mass (SSFM), seedling shoot dry mass (SSDM) and the proportion of seeds sprouted in the first count (FC) showed a reduction when treated with $S$. cerevisiae.

It is possible to observe that $R$. glutinis did not interfere negatively in any of the parameters related to germination. The fungicide was statistically similar to the control in all parameters, except the germination speed index (GSI), which increased from 24.80 to 31.74 with the application of fungicide.

Yeasts, in general, were not effective in improving germination parameters, while Fedotov, Shoba, Fedotova, Stepanov and Streletsky (2017) when using a concentration of $4 \times 10^{7} \mathrm{~mL}^{-1}$ cells in different yeasts such as Rhodotorula mucilaginosa, S. cerevisiae and Cryptococcus spp. were able to stimulate the metabolism of wheat seeds, making the germination process faster.

The fungicide did not interfere in a large part of the parameters, however, it resulted in an increase in the germination speed index. For the first count on the fourth day after germination and for the germination test, the highest values were obtained when treated with fungicide.

Therefore, yeasts have not shown efficacy in parameters related to germination, however, research must advance mainly in terms of dosages and treatment methods that do not harm germination. 
In the accelerated aging test (Table 3), there was no significant difference between treatments for germinated on the eighth day. For the other variables, there was a statistical difference between treatments. When compared with non-aged treatment, all variables show statistical difference with the same.

Table 3. Percentage of wheat seeds treated with yeasts submitted to accelerated aging germinated on the fourth day (G4), on the eighth day (G8), not germinated on the eighth day (NG8) and abnormal seeds quantified on the eighth day (A8) after the installation of the experiment. Marechal Cândido Rondon, 2017

\begin{tabular}{lllll}
\hline Treatment & G4 & G8 & NG8 & A8 \\
\hline Control & $18.0 \mathrm{abA}$ & $67.5 \mathrm{aB}$ & $22.0 \mathrm{abB}$ & $10.5 \mathrm{abB}$ \\
P. guilliermondii & $14.0 \mathrm{bB}$ & $73.5 \mathrm{aA}$ & $20.5 \mathrm{abB}$ & $6.0 \mathrm{bB}$ \\
Z. hellenicus & $28.0 \mathrm{abA}$ & $72.0 \mathrm{aA}$ & $23.0 \mathrm{abB}$ & $5.0 \mathrm{bB}$ \\
S. cerevisiae & $20.0 \mathrm{abA}$ & $73.5 \mathrm{aA}$ & $18.0 \mathrm{abB}$ & $8.5 \mathrm{bB}$ \\
C. laurentii & $23.0 \mathrm{abA}$ & $71.0 \mathrm{aA}$ & $21.0 \mathrm{abB}$ & $8.0 \mathrm{bB}$ \\
C. albicans & $15.0 \mathrm{abB}$ & $61.0 \mathrm{aB}$ & $28.5 \mathrm{aA}$ & $10.5 \mathrm{abB}$ \\
R. glutinis & $29.0 \mathrm{aA}$ & $66.5 \mathrm{aB}$ & $24.0 \mathrm{abB}$ & $9.5 \mathrm{bB}$ \\
Fungicide & $14.5 \mathrm{abB}$ & $65.0 \mathrm{aB}$ & $11.5 \mathrm{bB}$ & $23.5 \mathrm{aA}$ \\
Treat. not aged & $30.5 \mathrm{~A}$ & $86.5 \mathrm{~A}$ & $12.5 \mathrm{~B}$ & $1.00 \mathrm{~B}$ \\
DMS & 12.69 & 17.91 & 11.78 & 11.49 \\
CV\% & 29.67 & 12.63 & 29.21 & 62.50 \\
Overall Average & 21.33 & 70.72 & 20.11 & 9.17 \\
\hline
\end{tabular}

Note. Averages followed by the same lower case letter in the column, do not differ statistically, Tukey test at the level of $\mathrm{p} \leq 0.05$. Means followed by the same capital letter in the column, do not differ from the treatment that has not undergone aging, Dunnet test at the level of $\mathrm{p} \leq 0.05$.

The seeds treated with $P$. guilliermondii, $C$. albicans and fungicide were disadvantaged in germination when aged showing that the treatments interfere negatively accelerating the process of seeds degradation over time. The other treatments were similar to non-aged. In general, yeasts were not effective in increasing germination on the fourth day.

On the eighth day, yeasts were also not effective for adding sprouted seeds. Treatments with C. albicans, $R$. glutinis, fungicide and the control were also disadvantaged with aging, showing that under high temperature conditions germination is impaired.

In the variable non-germinated seeds (hard, dormant and dead), only the treatment with C. albicans differed from the non-aged treatment and the others, being disadvantaged with the accelerated aging due to the high number of non-germinated seeds. This behavior shows that over time the presence of this yeast impairs seed germination.

The abnormal seeds (damaged, deformed or deteriorated) have no statistical difference between the treatments and the control. When compared to non-aged treatment, fungicide treatment was disadvantaged with aging.

The results for percentage of seeds germinated on the eighth day submitted to accelerated aging did not obtain significant difference between the treatments and the general average $70.72 \%$ is similar to the work of Ohlson, Krzyzanowski, Caieiro and Panobianco (2010) who obtained $72 \%$ of normal seedlings in lot 4 of cultivar CD 104 of wheat after accelerated aging test at $43{ }^{\circ} \mathrm{C}$ for $48 \mathrm{~h}$.

In the results of the cold test (Table 4), the percentage of seeds germinated on the fourth day showed a significant difference between treatments. P. guilliermondii accelerated germination, presenting $79.00 \%$ of the seeds germinated on the fourth day after sowing, surpassing the fungicide. 
Table 4. Percentage of wheat seeds treated with yeasts submitted to cold test germinated on the fourth day (G4), on the eighth day (G8), not germinated on the eighth day (NG8) and abnormal seeds quantified at eighth day (A8) after the installation of the experiment. Marechal Cândido Rondon, 2017

\begin{tabular}{lllll}
\hline Treatment & G4 & G8 & NG8 & A8 \\
\hline Control & $59.0 \mathrm{abA}$ & $77.0 \mathrm{aA}$ & $11.5 \mathrm{aA}$ & $11.5 \mathrm{aA}$ \\
P. guilliermondii & $79.0 \mathrm{aA}$ & $85.5 \mathrm{aA}$ & $12.0 \mathrm{aA}$ & $2.5 \mathrm{aB}$ \\
Z. hellenicus & $54.0 \mathrm{bA}$ & $81.5 \mathrm{aA}$ & $13.0 \mathrm{aA}$ & $5.5 \mathrm{aB}$ \\
S. cerevisiae & $76.0 \mathrm{abA}$ & $81.5 \mathrm{aA}$ & $14.0 \mathrm{Aa}$ & $4.5 \mathrm{aB}$ \\
C. laurentii & $55.5 \mathrm{abA}$ & $73.0 \mathrm{aA}$ & $18.0 \mathrm{aA}$ & $9.0 \mathrm{aB}$ \\
C. albicans & $69.5 \mathrm{abA}$ & $79.0 \mathrm{aA}$ & $18.0 \mathrm{aA}$ & $3.0 \mathrm{aB}$ \\
R. glutinis & $73.5 \mathrm{abA}$ & $82.5 \mathrm{aA}$ & $11.5 \mathrm{aA}$ & $6.0 \mathrm{aB}$ \\
Fungicide & $52.0 \mathrm{bA}$ & $82.0 \mathrm{aA}$ & $8.0 \mathrm{aA}$ & $10.0 \mathrm{aB}$ \\
Treat. not subjected to cold & $30.5 \mathrm{~B}$ & $86.5 \mathrm{~A}$ & $12.5 \mathrm{~A}$ & $1.01 \mathrm{~B}$ \\
DMS & 20.8 & 14.78 & 10.04 & 9.32 \\
CV\% & 17.01 & 9.11 & 38.03 & 78.93 \\
Overall Average & 61.0 & 80.94 & 13.16 & 5.89
\end{tabular}

Note. Averages followed by the same lower case letter in the column, do not differ statistically from each other, tukey test at the level of $p \leq 0.05$. Averages followed by the same capital letter in the column do not differ from the treatment that was not subjected to cold, Dunnet test at the level of $p \leq 0.05$.

Germination and the percentage of normal seedlings were favored with the cold test when compared to the non-cooled treatment. Germination is slower without the stress of cold, presenting only $30.50 \%$ of the seeds germinated on the fourth day.

On the eighth day, the percentages of normal seedlings are similar to each other in all treatments with averages of 73.0 to $85.5 \%$, similar to cultivar Itaipu in the work of De Oliveira et al. (2020) who obtained $86.0 \%$ of normal seedlings when zero dose of the Stimulate ${ }^{\circledR}$ (4-indole-3-ylbutyric acid + gibberellic acid + kinetin) was applied and $85.0 \%$ when the highest dose of $1 \mathrm{~L} \mathrm{ha}^{-1}$ was applied after cold test with exposure of three to five days at $10^{\circ} \mathrm{C}$.

In the seed health test, the percentage of seeds showing fungal structures of the pathogens Bipolaris sorokiniana, Fusarium graminearum, Pyricularia grisea and Stagonospora nodorum can be seen in Table 5. The statistical analysis showed a significant effect $(\mathrm{p}<0.05)$ for the factor studied.

Table 5. Percentage of healthy wheat seeds (HS) and seeds showing structures characteristic of Bipolaris sorokiniana (BS), Fusarium graminearum (FG), Pyricularia grisea (PG), Stagonospora nodorum (SN) after treatment with yeast, fungicide and distilled water. Marechal Cândido Rondon, 2017

\begin{tabular}{llllll}
\hline Treatment & BS & FG & PG & SN & HS \\
\hline Control & $17.00 \mathrm{bc}$ & $43.0 \mathrm{a}$ & $28.25 \mathrm{ab}$ & $21.25 \mathrm{cde}$ & $1.0 \mathrm{~b}$ \\
P. guilliermondii & $12.5 \mathrm{c}$ & $41.5 \mathrm{a}$ & $27.75 \mathrm{ab}$ & $17.25 \mathrm{de}$ & $0.25 \mathrm{~b}$ \\
Z. hellenicus & $20.5 \mathrm{abc}$ & $41.75 \mathrm{a}$ & $31.5 \mathrm{a}$ & $35.25 \mathrm{ab}$ & $0.5 \mathrm{~b}$ \\
S. cerevisiae & $27.0 \mathrm{ab}$ & $44.25 \mathrm{a}$ & $35.5 \mathrm{a}$ & $34.0 \mathrm{~b}$ & $0.0 \mathrm{~b}$ \\
C. laurentii & $20.0 \mathrm{abc}$ & $39.0 \mathrm{a}$ & $25.5 \mathrm{ab}$ & $12.5 \mathrm{e}$ & $0.5 \mathrm{~b}$ \\
C. albicans & $24.25 \mathrm{ab}$ & $41.0 \mathrm{a}$ & $25.25 \mathrm{ab}$ & $32.5 \mathrm{bc}$ & $0.0 \mathrm{~b}$ \\
R. glutinis & $28.5 \mathrm{a}$ & $43.5 \mathrm{a}$ & $32.75 \mathrm{a}$ & $27.0 \mathrm{bcd}$ & $0.25 \mathrm{~b}$ \\
Fungicide & $10.5 \mathrm{c}$ & $1.25 \mathrm{~b}$ & $16.5 \mathrm{~b}$ & $45.75 \mathrm{a}$ & $11.75 \mathrm{a}$ \\
CV\% & 23.16 & 17.95 & 21.56 & 19.41 & 35.24 \\
Overall Average & 20.03 & 36.90 & 27.87 & 28.44 & 1.78
\end{tabular}

Note. Averages followed by the same lower case letter in the column, do not differ statistically from each other, tukey test at the level of $\mathrm{p} \leq 0.05$. 
Yeasts did not effectively reduce the level of seed contamination. However, in the work of Matić, Spadaro, Garibaldi and Gullino (2014) seeds treated with P. guilliermondii reduced the infection rate by Fusarium fujikuroi to $14.3 \%$ in rice seeds, compared to untreated seeds ( $97.7 \%$ of infection).

Yeasts were not efficient for the pathogens Fusarium graminearum, Pyricularia grisea and Stagonospora nodorum. The isolate $Z$. hellenicus and the fungicide increased the infestation by $S$. nodorum in the seeds.

Fokkema, Denhouter, Kosterman and Nelis (1979) found that diseases in the field were less severe when $C$. laurentii was present in the leaf blade. However, in this work, no efficacy of this yeast was observed, requiring further studies to confirm the benefits of the yeast against Stagonospora nodorum, the causal agent of glume spot.

The fungicide treatment showed the highest percentage of healthy seeds (Table 5), showing that yeasts did not present the control mechanisms mentioned as antibiosis or competition for the ecological niche. In general, research should continue regarding the concentration of yeast cells for seed treatment and for field spraying.

\section{Conclusion}

The yeasts tested were not efficient in the management of wheat diseases by seed treatment and by leaf application under the conditions of the experiment. The yeast Zygoascus hellenicus, when applied in aerial part, increased the productivity.

\section{Acknowledgements}

The authors would like to thank Fundação Araucária for granting a scholarship for the development of this work and the State University of Western Paraná for their support in the research.

\section{References}

Alves, G. C. S., Santos, L. de C., Duarte, H. D. S. S., Dias, V., Zambolim, L., \& Rocha, M. R. da. (2015). Escala diagramática para quantificação da ferrugem da folha do trigo. Multi-Science Journal, 1(1), 128-133. https://doi.org/10.33837/msj.v1i1.59

Barnett, H. L., \& Hunter, B. B. (1998). Illustrated genera of imperfect fungi (4th ed., p. 218). Minnesota, APS Press.

Battistus, A. G., Kuhn, O. J., Stangarlin, J. R., Hoffmann, M. R. B., Stülp, J. L., \& Istchuk, N. A. (2013). Comportamento da cultura do trigo tratado com enraizador e bioativador de plantas. Scientia Agraria Paranaensis, 12(1), 17-29. https://doi.org/10.18188/1983-1471/sap.v12n1p17-29

Brasil, Ministério da Agricultura e Reforma Agrária. (2009). Regras para análise de sementes (p. 399). Brasília, DF: SNDA/DNDV/CLAV.

Chavarria, G., Rosa, W. P. D., Hoffmann, L., \& Durigon, M. R. (2015). Regulador de crescimento em plantas de trigo: Reflexos sobre o desenvolvimento vegetativo, rendimento e qualidade de grãos. Revista Ceres, 62(6), 583-588. https://doi.org/10.1590/0034-737X201562060011

De Oliveira, S., Lemes, E., Neves, E., Ritter, R., De Mendonça, A., \& Meneghello, G. (2020). Uso de biorregulador e seus reflexos na produção e na qualidade de sementes de trigo. Scientia Plena, 16(1). https://doi.org/10.14808/sci.plena.2020.011501

Fanan, S., Lima, T. C., \& Marcos Filho, J. (2006). Avaliação do vigor de sementes de trigo pelos testes de envelhecimento acelerado e de frio. Revista Brasileira de Sementes, 28(2), 152-158. https://doi.org/10.1590/ S0101-31222006000200021

FAO (Food and Agriculture Organization of the United Nations). (2018). Retrieved May 25, 2020, from http://www.fao.org/faostat/en/\#data/QC

Fedotov, G. N., Shoba, S. A., Fedotova, M. F., Stepanov, A. L., \& Streletsky, R. A. (2017). Soil yeasts and their role in seed germination. Eurasian Soil Science, 50(5), 573-579. https://doi.org/10.1134/S10642293170 50052

Fokkema, N. J., Denhouter, J. G., Kosterman, Y. J. C., \& Nelis, A. L (1979). Manipulation of yeasts on fieldgrown wheat leaves and their antagonistic effect on Cochliobolus sativus and Septoria nodorum. Transactions of the British Mycological Society, 72(1), 19-29. https://doi.org/10.1016/S0007-1536(79) 80003-0 
Heling, A. L. (2016). Isolamento, identificação e avaliação do potencial de leveduras como agentes de proteção de plantas de feijoeiro ao crestamento bacteriano comum (Master's Thesis, State University of Western of Paraná, Marechal Cândido Rondon, Brazil).

Hossen, D. de C., Corrêa Júnior, E. dos S., Guimarães, S., Nunes, U. R., \& Galon, L. (2014). Tratamento químico de sementes de trigo. Pesquisa Agropecuária Tropical, 44(1), 104-109. https://doi.org/10.1590/ S1983-40632014000100014

INMET (Instituto Nacional de Meteorologia). (2017). Retrieved May 28, 2018, from http://www.inmet.gov.br/ sonabra/pg_dspDadosCodigo_sim.php?QTgyMA

James, W. C. (1971). An illustrated series of assessment keys for plant diseases, their preparation and usage. Canadian Plant Disease Survey, 51, 39-65.

Libardi, V. C. de M., \& Costa, M. B. da. (1997). Consumo d'água da cultura do trigo (Tricutum aestivum L.). Revista da FZVA, 4(1), 16-23.

Lima, T. C., Medina, P. F., \& Fanan, S. (2006). Avaliação do vigor de sementes de trigo pelo teste de envelhecimento acelerado. Revista Brasileira de Sementes, 28(1), 106-113. https://doi.org/10.1590/ S0101-31222006000100015

Liu, J., Sui, Y., Wisniewski, M., Droby, S., \& Liu, Y. (2013). Utilization of antagonistic yeasts to manage postharvest fungal diseases of fruit. International Journal of Food Microbiology, 167(2), 153-160. https://doi.org/10.1016/j.ijfoodmicro.2013.09.004

Machado, J. da C., Pereira, J. M., Valle, L. A. C., \& Alvisi, M. A. G. L. (2009). Manual de análise sanitária de sementes. MAPA/ACS.

Maciel, J. L. N., Danelli, A. L. D., Boaretto, C., \& Forcelini, C.A. (2013). Diagrammatic scale for assessment of blast on wheat spikes. Summa Phytopathologica, 39(3), 162-166. https://doi.org/10.1590/S0100-54052013 000300003

Maguire, J. D. (1962). Speed of germination-aid in selection and evaluation for seedling emergence and vigor 1. Crop Science, 2(2), 176-177. https://doi.org/10.2135/cropsci1962.0011183X000200020033x

Marinho, J. de L., Bazzo, J. H. B, Cardoso, C. P., Zucareli, C., \& Fonseca, I. C. de B. (2018). Produtividade e qualidade fisiológica de sementes de cultivares de trigo em diferentes densidades de semeadura. Colloquium Agrariae, 14(3), 122-131. https://doi.org/10.5747/ca.2018.v14.n3.a234

Matić, S., Spadaro, D., Garibaldi, A., \& Gullino, M. L. (2014). Antagonistic yeasts and thermotherapy as seed treatments to control Fusarium fujikuroi on rice. Biological Control, 73, 59-67. https://doi.org/10.1016/ j.biocontrol.2014.03.008

Medeiros, F. H. V., Silva, J. C. P. da, \& Pascholati, S. F. (2018). Controle biológico de doenças de plantas. In L. Amorim, J. A. M. Rezende, \& A. Bergamin Filho (Eds.), Manual de Fitopatologia: princípios e conceitos (5th ed., Vol. 1, pp. 267-270). Ouro Fino, Editora Agronômica Ceres.

Mello, M. R. F., Silveira, E. B., Viana, I. O., Guerra, M. L., \& Mariano, R. L. R. (2011). Uso de antibióticos e leveduras para controle da podridão-mole em couve-chinesa. Horticultura Brasileira, 29(1), 78-83. https://doi.org/10.1590/S0102-05362011000100013

Mohamed, M. F., Thalooth, A. T., Essa, R. E. Y., \& Gobarah, M. E. (2018). The stimulatory effects of tryptophan and yeast on yield and nutrient status of wheat plants (Triticum aestivum) grown in newly reclaimed soil. Middle East Journal of Agriculture Research, 7(1), 27-33.

Nakagawa, J. (1999). Testes de vigor baseados no desempenho das plântulas. In F. C. Krzyzanowski, R. D. Vieira, \& J. B. França Neto (Eds.), Vigor de sementes: Conceitos e testes (Vol. 1, pp. 1-24). Londrina, Abrates.

Ohlson, O. D. C., Krzyzanowski, F. C., Caieiro, J. T., \& Panobianco, M. (2010). Teste de envelhecimento acelerado em sementes de trigo. Revista Brasileira de Sementes, 32, 118-124. https://doi.org/10.1590/ S0101-31222010000400013

Oliveira, E. L. (2003). Sugestão de adubação e calagem para culturas de interesse econômico no estado do Paraná (No. 128). Instituto Agronômico do Paraná, Brazil.

Pereira, R. A., Costa, C. M. L., \& Lima, E. M. (2019). O impacto dos agrotóxicos sobre a saúde humana e o meio ambiente. Revista Extensão, 3(1), 29-37. 
Prando, A. M., Zucareli, C., Fronza, V., Oliveira, F. A. de, \& Oliveira Junior, A. (2013). Características produtivas do trigo em função de fontes e doses de nitrogênio. Pesquisa Agropecuária Tropical, 43(1), 34-41. https://doi.org/10.1590/S1983-40632013000100009

Ribeiro Júnior, W. Q., Ramos, M. L. G., Vasconcelos, U., Trindade, M. da G., Ferreira, F. M., Siqueira, M. M. H, ... Durães, F. O. M. (2006). Fenotipagem para tolerância à seca visando o melhoramento genético do trigo no cerrado (Circular Técnica Online, 21, p. 24). Passo Fundo, Embrapa Trigo.

Roberts, R. G. (1990). Postharvest biological control of gray mold of apple by Cryptococcus laurentii. Phytopathology, 80(6), 526-530. https://doi.org/10.1094/Phyto-80-526

Silva Júnior, G. J. da, \& Behlau, F. (2018). Controle químico. In L. Amorim, J. A. M. Rezende, \& A. Bergamin Filho (Eds.), Manual de Fitopatologia: princípios e conceitos (5th ed., Vol. 1, pp. 239-260). Ouro Fino, Editora Agronômica Ceres.

Silva, S. R., Bassoi, M. C., \& Foloni, J. S. S. (2017). Informações técnicas para a safra 2017: Trigo e triticale (p. 242). Brasília, Embrapa Soja-Livro técnico (INFOTECA-E).

Thapa, R., Brown-Guedira, G., Ohm, H. W., Mateos-Hernandez, M., Wise, K. A., \& Goodwin, S. B. (2016). Determining the order of resistance genes against Stagonospora nodorum blotch, Fusarium head blight and stem rust on wheat chromosome arm 3BS. BMC Research Notes, 9(1), 58. https://doi.org/10.1186/ s13104-016-1859-Z

Wachowska, U., Kucharska, K., Jędryczka, M., \& Łobik, N. (2013). Microorganisms as biological control agents against Fusarium pathogens in winter wheat. Polish Journal of Environmental Studies, 22(2), 591-597.

Wightwick, A., Walters, R., Allison, G., Reichman, S., \& Menzies, N. (2010). Environmental risks of fungicides used in horticultural production systems. Fungicides, 273-304. https://doi.org/10.5772/13032

Wilcox, J., \& Makowski, D. (2014). A meta-analysis of the predicted effects of climate change on wheat yields using simulation studies. Field Crops Research, 156, 180-190. https://doi.org/10.1016/j.fcr.2013.11.008

Zadoks, I. C., Chang, T. T., \& Konzak, C. F. A. (1974). Decimal code for the growth stages of cereals. Weed Research, 14(6), 415-421. https://doi.org/10.1111/j.1365-3180.1974.tb01084.x

\section{Copyrights}

Copyright for this article is retained by the author(s), with first publication rights granted to the journal.

This is an open-access article distributed under the terms and conditions of the Creative Commons Attribution license (http://creativecommons.org/licenses/by/4.0/). 